\title{
A preliminary study on the action of cassava on thyroid iodine metabolism in rats
}

\author{
By M. van der VELDEN* aNd J. KINTHAERT, \\ Department of Radioisotopes, Saint Pierre Hospital, \\ Free University of Brussels, Brussels, Belgium \\ AND S. ORTS \\ Department of Nutrition, CEMUBAC-IRSAC, \\ Lwiro, Kivu, Republic of Zaire \\ AND A. M. ERMANS \\ Department of Radioisotopes, Saint Pierre Hospital, \\ Free University of Brussels, Brussels, Belgium

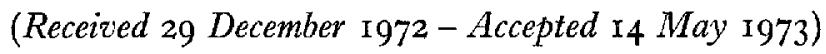

\begin{abstract}
r. 'The ingestion of cassava (Manihot esculenta Crantz) by rats increased the plasma thiocyanate concentration and reduced the thyroid iodine content and the plasma protein-bound jodine.

2. Administration of increasing doses of thiocyanate raised the plasma thiocyanate concentration and reduced the thyroid iodine content and the plasma protein-bound iodine.

3. In producing these effects, the daily ingestion of Io $\mathrm{g}$ cassava root containing $1.6 \mathrm{mg}$ cyanide was approximately equivalent to a daily intake of about $\mathrm{x}-2 \mathrm{mg}$ thiocyanate.

4. These results suggest that the antithyroid action of cassava is the result of the production of thiocyanate by the rat from cyanide arising from the cyanogenic glucosides present in this food.
\end{abstract}

The goitrogenic action of cassava (Manihot esculenta Crantz) was first demonstrated by Ekpechi ( 1967$)$ in experimental studies on rats. He attributed this action to the presence in cassava of a goitrogen which acts like the thionamide group of antithyroid drugs.

Studies on endemic goitre in Idjwi island in Lake Kivu, Republic of Zaire, suggest that cassava, which is a common food in the island, could have a determining role in the pathogenesis of goitre in this area (Delange \& Ermans, I97I). The findings of Delange \& Ermans (197I) suggest that the action of this food is due to a thiocyanatelike substance. The action of thiocyanate on the thyroid gland has been described by Wolff (r964). The high plasma concentrations of thiocyanate observed in all inhabitants of Idjwi island (Ermans, Thilly, Vis \& Delange, I969) support this view.

A similar increase in the plasma thiocyanate concentration in patients with nutritional ataxic neuropathy, who all had a history of a monotonous diet of cassava derivatives, has been observed by Osuntokun, Monekosso \& Wilson (1969).

Thiocyanate is known to be produced in vegetables of the Brassica genus by the

* For reprints: Service des Radioisotopes, Hôpital Saint Pierre, Rue Haute 322, rooo Bruxelles, Belgique. 
hydrolysis of various thioglucosides by thioglucosidase present in these plants (Van Etten, Daxenbichler \& Wolff, I969).

Thiocyanate can also be formed in the animal body from cyanide, and cassava is known to contain cyanogenic glucosides (consisting of $93 \%$ linamarin and $7 \%$ lotaustralin) (Bisset, Clapp, Coburn, Ettlinger \& Long, 1969). Enzymic hydrolysis of these compounds yields hydrogen cyanide when plant tissue is traumatized; hydrolysis may also be caused by intestinal microflora (Coop \& Blakley, r949).

After ingestion of cassava, cyanide is absorbed by the gastrointestinal tract and rapidly converted into thiocyanate by an enzymic mechanism involving sulphurtransferase, which is widely distributed in various organs (Rosenthal, 1948). Sulphur for the conversion of cyanide into thiocyanate is derived from thiosulphate (Lang, I933) or 3-mercaptopyruvate (Fiedler \& Wood, 1956), which are catabolic products of sulphur amino acids and are rapidly converted enzymically into thiocyanate by sulphurtransferases, which are widely distributed in the animal body (Himwich \& Saunders, I948).

The aim of the present study was to test the hypothesis that the antithyroid action of cassava is induced by the endogenous production of thiocyanate. The following points were investigated.

(r) The possible presence of thioglycosides in cassava to see if any preformed thiocyanate might be ingested.

(2) The influence of cassava ingestion on the plasma thiocyanate concentration. This effect was compared with that produced by ingestion of various doses of thiocyanate.

(3) The effects produced by ingestion of cassava on two criteria of thyroid metabolism, the thyroid iodine content and the plasma protein-bound iodine, compared with those produced by ingestion of various doses of thiocyanate.

\section{EXPERIMENTAL}

Source of cassava

Cassava flour and roots were obtained from the goitrous region of Idjwi island, Lake Kivu, Republic of Zaire. Ten samples of cassava flour were obtained from different villages of the island and fresh roots of four different types of cassava recognized by the inhabitants of the island. Cassava flour is prepared by peeling the roots, drying the pulp in the sun for $\mathrm{I}_{5} \mathrm{~d}$ and then pounding the dried pulp. Additionally, a cassava flour was prepared from the integument by peeling the cassava root, drying the peel in the sun, and then pounding.

\section{Cassava analysis}

Estimation of cyanide liberated from cassava. Distilled water ( $10 \mathrm{ml}$ ) was added to 2-4 g cassava root or cassava flour and the mixture was incubated at $35^{\circ}$ for $24 \mathrm{~h}$. Liberated cyanide was drawn away by a stream of air and trapped in a solution of sodium carbonate $(5 \circ \mathrm{g} / \mathrm{l})$. Cyanide was estimated by the method of Aldridge (1945). This method does not differentiate cyanide from thiocyanate. It was checked that 
thiocyanate was not drawn away by the stream of air and therefore did not interfere with cyanide estimation. Ten samples of cassava flour and the fresh roots of the four different types of cassava were analysed.

Estimation of thiocyanate liberated by thioglucosidase action. Distilled water (ro $\mathrm{ml}$ ) and a thioglucosidase extract were added to $2-4 \mathrm{~g}$ cassava root or cassava flour and incubated at room temperature for $\mathbf{2 h}$. The thioglucosidase extract was prepared by the method of Schwimmer (1960) and its activity checked on an extract of brussels sprouts prepared by the method of Gmelin \& Virtanen (I960). Liberated cyanide was drawn away from the incubation medium by a stream of air. Thiocyanate was estimated by the method of Aldridge (1945).

\section{Diets}

The low-iodine test diet used in this work was obtained (as a powder) from the Nutritional Biochemicals Corporation, Cleveland, Ohio. Its composition was $(\mathrm{g} / \mathrm{kg})$ : yellow maize meal (grown in an iodine-deficient area) 780 , wheat gluten I 80, brewers' yeast 20, calcium carbonate 10, and sodium chloride ro (Remington, 1937).

The diet was prepared for the rats by mixing $\mathrm{I} 500 \mathrm{~g}$ test diet powder with $600 \mathrm{ml}$ distilled water and cooking the resulting dough at $225^{\circ}$ for $90 \mathrm{~min}$.

Test diets supplemented with iodide or various amounts of thiocyanate were obtained by adding appropriate amounts of potassium iodide or potassium thiocyanate to the distilled water before mixing. It was checked that iodide or thiocyanate added to the test diet was completely recovered after cooking.

The cassava diets consisted of either raw, unpeeled cassava root or cassava flour. The flour was cooked by heating for $2 \mathrm{~h}$ in distilled water to obtain a dough.

\section{Design of experiments}

Three experiments were performed.

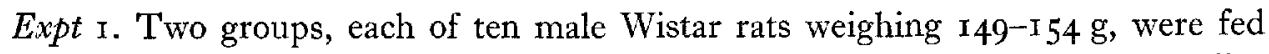
on the following diets for $2 \mathrm{I} d$, one group on each diet, each rat receiving daily: (a) rog test diet or $(b)$ Io g cassava root.

Expt 2. Two groups, each of twelve male Long Evans rats weighing $225^{-292} \mathrm{~g}$, were given the following diets for $28 \mathrm{~d}$, one group on each diet, each rat receiving daily: (a) $25 \mathrm{~g}$ test diet or (b) $30 \mathrm{~g}$ cooked cassava flour.

Expt 3. Seven groups, each of nine male Wistar rats weighing III-I $38 \mathrm{~g}$, were given the following dicts for $2 \mathrm{I} \mathrm{d}$, one group on each diet, each rat receiving daily: (a) $\mathrm{I} 4 \mathrm{~g}$ test diet; (b) $\mathrm{I} 4 \mathrm{~g}$ test diet + an iodide supplement of $10 \mu \mathrm{g}$; $(c) \mathrm{I} 4 \mathrm{~g}$ test diet + a thiocyanate supplement of $0 \cdot \mathrm{I} \mathrm{mg} ;(d)$ I $4 \mathrm{~g}$ test diet + a thiocyanate supplement of I mg; $(e)$ I $4 \mathrm{~g}$ test diet + a thiocyanate supplement of $2 \mathrm{mg} ;(f) \mathrm{I} 4 \mathrm{~g}$ test $\operatorname{diet}+\mathrm{a}$ thiocyanate supplement of $10 \mathrm{mg}$; or $(\mathrm{g})$ lo $\mathrm{g}$ cassava root $+6 \mathrm{~g}$ test diet.

At the end of the period on the diet, rats were exsanguinated under diethyl ether anaesthesia. Blood was collected for determination of thiocyanate and plasma proteinbound iodine. The thyroid glands were collected for determination of their iodine content. 
Table 1. Cyanide content ( $\mathrm{mg} / \mathrm{kg}$ ) of cassava

(Mean values with their standard errors; numbers of samples in parentheses; four assays on each sample)

\begin{tabular}{|c|c|c|c|c|}
\hline \multirow[b]{2}{*}{ Cassava } & \multicolumn{2}{|c|}{ Pulp } & \multicolumn{2}{|c|}{ Integument } \\
\hline & Mean & $\mathrm{SE}$ & Mean & $\mathrm{SE}$ \\
\hline Flour & 30 & $22(10)$ & $\mathrm{I}_{45}$ & 139 (10) \\
\hline Fresh roots $\dagger$ & $\begin{array}{l}163 \\
180\end{array}$ & $\begin{array}{r}\text { II } \\
3\end{array}$ & $\begin{array}{l}227 \\
284\end{array}$ & $\begin{array}{l}14 \\
27\end{array}$ \\
\hline & $\begin{array}{l}454 \\
698\end{array}$ & $\begin{array}{l}3 \\
27 \\
88\end{array}$ & $\begin{array}{l}446 \\
963\end{array}$ & $\begin{array}{r}23 \\
112\end{array}$ \\
\hline
\end{tabular}

+ Values for four different types of cassava recognized by the inhabitants of Idjwi island.

\section{Blood and thyroid analysis}

Thiocyanate in serum was determined by the method of Aldridge ( 1945 ) as modified by Michajlowski \& Langer (1959).

The plasma protein-bound iodine and the iodine content of the thyroid were measured by means of a modification (Ermans, Kinthaert, Delcroix \& Collard, r968) of the Barker, Humphrey \& Soley (195I) method using a Technicon AutoAnalyzer (Technicon Instruments Co. Ltd, Basingstoke, Hants.). Iodine in the thyroid was estimated after homogenization of one lobe in $0.5 \mathrm{ml}$ tris- $\mathrm{NaCl}$ buffer. This homogenate was hydrolysed by $5 \mathrm{M}-\mathrm{NaOH}$ at $80-100^{\circ}$ for $30 \mathrm{~min}$, then neutralized with conc. $\mathrm{HCl}$, and the volume was brought up to $5 \mathrm{ml}$ with distilled water.

RESULTS

Analysis of cassava

The cyanide content after incubation of the pulp of cassava roots was very variable and ranged from $\mathrm{r} 63$ to $698 \mathrm{mg}$ cyanide $/ \mathrm{kg}$ fresh tissue. The integument of the roots gave higher values (Table I). In contrast, cassava flour yielded an average of about $30 \mathrm{mg}$ cyanide $/ \mathrm{kg}$.

None of the ten samples of cassava flour produced any trace of thiocyanate after incubation with a thioglucosidase extract. Under the same conditions, extracts of brussels sprouts yielded $40-80 \mathrm{mg}$ thiocyanate $/ \mathrm{kg}$ fresh tissue.

\section{Effects on plasma thiocyanate concentration}

Table 2 shows that chronic ingestion of cassava root significantly increased the plasma thiocyanate concentration compared with that in control rats. The cassava root used in Expts $\mathrm{I}$ and 3 released after incubation $\mathrm{r} 6 \mathrm{r} \pm 19 \mathrm{mg}$ cyanide/ $\mathrm{kg}$ (mean value with standard error).

In Table 3 the increase in the plasma thiocyanate concentration induced by cassava ingestion in Expt 3 is compared with the values obtained by adding various amounts of thiocyanate to the test diet; it was close to that obtained with a daily ingestion of I mg thiocyanate. 
Table 2. Plasma thiocyanate concentration $(\mathrm{mg} / \mathrm{l})$ in rats after ingestion of cassava

(Mean values with their standard crrors; numbers of rats in each group in parentheses)

\begin{tabular}{|c|c|c|c|c|c|}
\hline \multirow[b]{2}{*}{ Expt no. } & \multicolumn{2}{|c|}{ Low-iodine test diet $\dagger$} & \multicolumn{2}{|c|}{ Cassava diet } & \multirow{2}{*}{$\begin{array}{c}\text { Significance of } \\
\text { difference } \\
(t \text { test })\end{array}$} \\
\hline & Mean & $\mathrm{SE}$ & Mean & SE & \\
\hline I (IO) & $5 \cdot 8$ & 0.8 & ro. 6 & $x \cdot 4 t$ & $P<0.00 \pi$ \\
\hline $2(\mathrm{I} 2)$ & $8 \cdot 0$ & 0.9 & II 6 & $2 \cdot 3 \S$ & $P<0.001$ \\
\hline $3(9)$ & $5 \cdot 0$ & 0.7 & $8 \cdot 8$ & $2 \cdot 7 t$ & $P<0.005$ \\
\hline
\end{tabular}

$\uparrow$ Supplied by the Nutritional Biochemicals Corporation, Cleveland, Ohio.

I Cassava roots.

$\S$ Cooked cassava flour.

Table 3. Effect of cassava diet or low-iodine test diet $\dagger$ supplemented with various amounts of thiocyanate on plasma thiocyanate concentration, thyroid iodine content and plasma protein-bound iodine in rats

(Mean values with their standard errors; diets given for $2 \mathrm{I} d$; nine rats/group; number of analysis in parentheses)

Diet

(Amount given daily/rat in parentheses)

Test diet (I $4 \mathrm{~g}$ )

Test diet + ro $\mu$ g iodine ( $14 \mathrm{~g}$ )

Cassava roots $(\mathrm{I} \circ \mathrm{g})+$ test $\operatorname{diet}(6 \mathrm{~g})$

Test diet $+0.1 \mathrm{mg}$ thiocyanate ( $\mathrm{x} / \mathrm{g}$ )

Test diet + I mg thiocyanate ( $14 \mathrm{~g}$ )

Test diet $+2 \mathrm{mg}$ thiocyanate ( $\mathrm{I} 4 \mathrm{~g}$ )

Test diet $+10 \mathrm{mg}$ thiocyanate (I $4 \mathrm{~g}$ )

$\overbrace{\text { Mean SE }}^{\begin{array}{c}\text { Plasma } \\ \text { thiocyanate } \\ \text { concentration } \\ (\mathrm{mg} / \mathrm{l})\end{array}} \overbrace{\text { Mean sE }}^{\begin{array}{c}\text { Thyroid } \\ \text { iodine } \\ \text { content } \\ (\mu \mathrm{g} / \mathrm{g})\end{array}}$

$5.0 \quad 0.7(9)$

$5 \cdot 5 \quad x+2(9)$

$8 \cdot 8 * 2 \cdot 7(9)$

$7.0 * 0.5(9)$

$9 \cdot 8 * \quad x \cdot 0(9)$

$10.5 * \quad 1 \times 7(9)$

$13 \cdot 3 * 3 \cdot 1(9)$

$\begin{array}{rr}70 \cdot 2 & 16 \cdot 8(5) \\ 696 \cdot 0 * & \text { I } 36 \cdot 0(6) \\ 26 \cdot 3 * & \text { I } 2 \cdot 8(6) \\ 90 \cdot 8 & \text { I } 3 \cdot 9(6) \\ 45 \cdot 0 & \text { 1 } 4 \cdot 3(6) \\ 29 \cdot 8 * & 8 \cdot 3(6) \\ 16 \cdot 5^{*} & 5 \cdot 8(6)\end{array}$

I8.0 $2 \cdot 1(2)$

$20 \cdot 6 \quad 3 \cdot I(5)$

II. I* $0.6(5)$

$18.6 \quad 0.8(5)$

I $2 \cdot 6 * \quad I \cdot I(4)$

$I I \cdot 5^{*} \quad 0.7(4)$

$9 \cdot 3^{*} \quad 1 \cdot 5(5)$

* Significantly different $(P<0.01)$ from value for controls on low-iodine test diet.

$\dagger$ Supplied by the Nutritional Biochemicals Corporation, Cleveland, Ohio.

\section{Effects on thyroid iodine metabolism}

No significant differences could be detected between the thyroid weights of rats in the different groups.

Ingestion of cassava root and administration of thiocyanate above $2 \mathrm{mg} / \mathrm{d}$ significantly $(P<0.01)$ reduced the thyroid iodine content below that of the control group in Expt 3 (Table 3). For rats given cassava, the reduction was $63 \%$ and was close to that produced by daily ingestion of more than $2 \mathrm{mg}$ thiocyanate. In contrast, rats given an iodine supplement showed a tenfold increase.

A significant reduction $\left(P<0^{\circ} \circ \mathrm{I}\right)$ in the plasma protein-bound iodine was observed after administration of thiocyanate in Expt 3 except for the $O^{\circ}$ I $\mathrm{mg}$ thiocyanate group (Table 3). The value of the plasma protein-bound iodine in rats ingesting cassava was close to that in rats dosed with more than $2 \mathrm{mg}$ thiocyanate. 


\section{DISCUSSION}

The findings confirm that the chronic ingestion of cassava by iodine-deficient rats induces important changes in iodine metabolism: a drastic depletion of the thyroid iodine content and a decrease in the plasma protein-bound iodine compared with those in animals given a control diet. No thyroid hyperplasia was induced under the experimental conditions used in the present experiments, presumably because of their short duration. Ingestion of cassava, whether as flour or fresh roots, produced a significant increase in the thiocyanate concentration in plasma. Depending on the investigation, this increase was $45-82 \%$ of the thiocyanate concentration observed in control groups. Compared with the changes produced by addition of thiocyanate to the diet (ranging from $O \cdot I$ to $10 \mathrm{mg}$ ), the increment produced by the ingestion of Io g cassava root was close to that produced by daily ingestion of around I $\mathrm{mg}$ thiocyanate (Table 3). A similar comparison based on the depletion of the thyroid iodine content and the plasma protein-bound iodine showed that a similar effect on these measurements was produced by daily ingestion of about $2 \mathrm{mg}$ thiocyanate (Table 3). These amounts of thiocyanate $(\mathrm{I}-2 \mathrm{mg}$ ) are close to those one might expect to find after the conversion of ingested cyanide. Indeed, given the cyanide content of cassava used ( $160 \mathrm{mg} / \mathrm{kg}$ ) and the amounts of cassava offered daily ( $10 \mathrm{~g}$ ), the quantitative conversion of ingested cyanide $(\mathrm{I} \cdot 6 \mathrm{mg})$ into thiocyanate could produce approximately $3.2 \mathrm{mg}$ thiocyanate.

The similarity between the increase in the plasma thiocyanate concentration and the changes in iodine metabolism induced on the one hand by cassava ingestion and on the other hand by ingestion of thiocyanate supports the hypothesis that the antithyroid action of cassava is induced by the endogenous production of thiocyanate. The addition of iodine to the diet did not modify the plasma thiocyanate concentration. Our analytical studies eliminated the possibility that thiocyanate was liberated from a thioglucoside precursor. The amount of cyanide which could be liberated from the cyanogenic glucosides present in cassava is consistent with the hypothesis that the thiocyanate found in plasma is of endogenous origin. A similar conclusion was reached by Osuntokun (1970) in experimental studies on rats fed on cassava derivatives. In conclusion, this preliminary study is consistent with the view that the antithyroid activity of cassava in rats is the result of the production in the rat of thiocyanate from cyanide obtained from the large amounts of cyanogenic glucosides present in this vegetable.

We are indebted to Miss G. Willems and Professor H. L. Vis, Head of the Department of Nutrition, Cemubac-Irsac (Lwiro, Kivu, Republic of Zaire), for providing the samples of cassava and to Miss F. Dubois for her excellent technical assistance.

This study was supported by research grants from Fonds de la Recherche Scientifique Médicale, Institut Belge de l'Alimentation et de la Nutrition, Belgium, under contract of the Ministère de la Politique Scientifique within the framework of the Association Euratom - University of Brussels - University of Pisa. 


\section{REFERENCES}

Aldridge, W. N. (1945). Analyst, Lond. 70, 474.

Barker, S. B., Humphrey, J. M. \& Soley, M. H. (195I). F. clin. Invest. 30, 55.

Bisset, F. H., Clapp, R. C., Coburn, R. A., Ettlinger, M. G. \& Long, L. Jr (I969). Phytochemistry 8, 2235.

Coop, I. E. \& Blakley, R. L. (I949). N.Z. Fl Sci. Tech. 31 A, I.

Delange, F. \& Ermans, A. M. (1971). Am. J. clin. Nutr. 24, 1354.

Ekpechi, O. L. (1967). Br. F. Nutr. 21, 537.

Ermans, A. M., Kinthaert, J., Delcroix, C. \& Collard, J. (1968). F. clin. Endocr. Metab. 28, 169.

Ermans, A. M., Thilly, C., Vis, H. L. \& Delange, F. (1960). In Endemic Goiter [J. B. Stanbury, editor]. Washington, DC: Pan American Health Organization.

Fiedler, H. \& Wood, J. L. (1956). F. biol. Chem. 222, 387.

Gmelin, R. \& Virtanen, A. I. (1960). Acta chem. scand. 14, 507.

Himwich, W. A. \& Saunders, J. P. (1948). Am. F. Physiol. 153, 348.

Lang, K. (1933). Biochem. Z. 259, 243.

Michajlowski, N. \& Langer, P. (1959). Z. Physiol. Chem. 3r2, 26.

Osuntokun, B. O. (1970). Br. F. Nutr. 24, 797 .

Osuntokun, B. O., Monekosso, G. L. \& Wilson, J. (1969). Br. med. F. i, 547.

Remington, J. (1937). F. Nutr. 13, 223 .

Rosenthal, O. (1948). Fedn Proc. Fedn Am. Socs exp. Biol. 7, т81.

Schwimmer, J. (1960). Acta chem, scand. 14, I439.

Van Etten, C. H., Daxenbichler, M. E. \& Wolf,, I. A. (1969). F. agric. Fd Chem. 17, 483 .

Wolff, J. (1964). Physiol. Rev. 44, 45. 